\title{
Response of Organic Plant Nutrient Sources on Productivity and Profitability of Groundnut (Arachis hypogaea L.) and Soil Fertility under Humid Zone of Southern Rajasthan
}

\author{
Hargilas* \\ Agricultural Research Station (MPUAT), Borwat farm, Banswara-327001, Rajasthan, India \\ *Corresponding author
}

K e y w o r d s
Groundnut, Organic
plant nutrient
sources, Yield,
Economics, Soil
fertility

\section{Introduction}

Groundnut (Arachis hypogaea L.) is an important oilseed and supplementary food crop of the world. It is fourth most important source of edible oil and third most important source of vegetable protein. Globally, the crop is raised on 26.5 million ha with a total production of 43.9 million tonnes. India ranks first in acreage of 4.69 million ha with second rank in production of 6.56 million tonnes and productivity of $1400 \mathrm{~kg} / \mathrm{ha}$ which is quite low 
as compared to other countries (DAC\&FW 2016). Among the various factors such as water stress, nutrient deficiency and competition of weeds are limited the productivity of groundnut. Groundnut removes fairly large quantities of nutrients from the soil. In fact, chemical fertilizers played key role to quick supply plant nutrients to soil but they have also played significant role to degradation of soil fertility and soil bio-ecosystem and increases water stress in the crop duration without inadequate manuring. Adequate manuring does not only improve the yield but also maintains the soil health and sustain the productivity (Laxminarayan and Patiram, 2005). Ghosh et al., (2002) further organic manures, valuable by-products of farming and allied industries, contribute to plant growth through their favourable effects on the physical, chemical and biological properties of soil. Many benefits attributed to organic manures have well been documented (Stevenson, 1994).

Nziguheba et al., (1998) also reported that addition of organic materials causes mineralization of more recalcitrant fraction of $P$ through increased microbial activity and resultant biochemical transformation. In groundnut, application of FYM at 10 to $15 \mathrm{tha}^{-}$ ${ }^{1}$ increased the pod and haulm yields and improved the yield parameters like shelling percentage, 100 seed weight and sound mature kernels compared to the recommended dose of fertilizers (Subrahmaniyan et al., 2000). Increased pod yield due to the application of pressmud either separately or in combination with inorganic fertilizer was reported by Sriramachandrasekaran (2001). The one of the constraint in increasing the area under organic groundnut production is lack of suitable organic production practices for different agro-climatic regions. The present investigation was aimed to study the response of organic plant nutrient sources on productivity and profitability of groundnut and soil fertility status under humid climatic zone of Southern Rajasthan.

\section{Materials and Methods}

A field experiment was conducted in consecutive three year of 2012-14 at Agricultural Research Station (MPUAT), Banswara (Rajasthan) to find out the response of organic plant nutrient sources on productivity and profitability of groundnut (Arachis hypogaea $\mathrm{L}$ ) and soil fertility. The site of experiment field is located at $23^{\circ} 33^{\prime} \mathrm{N}$ latitude, $74^{\circ} 27^{\prime} \mathrm{E}$ longitude at an altitude of 220 MSL. The climatic condition of location is humid throughout the rainy season with average annual rainfall of $885 \mathrm{~mm}$, mostly received from July to September and mild winter and extreme hot summer. The soil of the experimental field was clay loam in texture having $\mathrm{pH}$ 7.6, medium in organic carbon ( 0.56 per cent), available nitrogen (256 $\mathrm{kg} \mathrm{ha}^{-1}$ ) and medium in available phosphorus $\left(34.09 \mathrm{~kg} \mathrm{ha}^{-1}\right)$, high in available potassium $\left(290 \mathrm{~kg} \mathrm{ha}^{-1}\right)$. The experiment was laid out in randomized block design with twelve treatments and three replications. The treatments consists of $\mathrm{T}_{1}$ - FYM @ $4 \mathrm{t}+$ rock phosphate@260kg ha ${ }^{-1}$ (equivalent to $20 \mathrm{~kg}$ $\left.\mathrm{N}+60 \mathrm{~kg} \mathrm{P}_{2} \mathrm{O}_{5} \mathrm{ha}^{-1}\right), \mathrm{T}_{2}-\mathrm{FYM} @ 2.2 \mathrm{tha}^{-1}+$ bone meal@300kg ha ${ }^{-1}, \mathrm{~T}_{3}$ - vermicompost @ $1.5 \mathrm{t} \mathrm{ha}^{-1}+$ rock phosphate@225 $\mathrm{kg} \mathrm{ha}^{-1}, \mathrm{~T}_{4}$ -neem cake@400kg ha ${ }^{-1}+$ bone meal@280kg $\mathrm{ha}^{-1}, \mathrm{~T}_{5}$ - poultry manure @ $1.0 \mathrm{t} \mathrm{ha}^{-1}+$ rock phosphate@200kg ha ${ }^{-1}, \mathrm{~T}_{6}-\mathrm{T}_{1}+$ seed treated with biofetilizers, $\mathrm{T}_{7}-\mathrm{T}_{6}+$ gypsum @ $500 \mathrm{~kg}$ $\mathrm{ha}^{-1}, \mathrm{~T}_{8}-\mathrm{T}_{6}+$ gypsum application in two split @250 kg/ha before sowing and $250 \mathrm{~kg} / \mathrm{ha}$ at before flowering, $\mathrm{T}_{9}-\mathrm{T}_{8}+$ green manuring incorporated at $20 \mathrm{DAS}, \mathrm{T}_{10}-\mathrm{T}_{8}+$ crop residue mulching @ $4 \mathrm{t} / \mathrm{ha}, \mathrm{T}_{11}-\mathrm{T}_{8}+$ spray of BD500 and $\mathrm{T}_{12}$-absolutely control. The gross and net plot size was $3.5 \times 3.5 \mathrm{~m}$ and $3.0 \times 3.0$ $\mathrm{m}$, respectively. Farm yard manure, rock phosphate, bone meal, vermicompost, neem cake and poultry manure were applied 15 days 
before the sowing whereas, gypsum applied at 15 days before sowing and at before flowering in standing crop. Crop residues used as surface mulching between crop rows after crop sowing. Rhizobium culture was used as seed treatment. Application of BD 500 was done twice firstly on evening prior to a day before sowing and secondly 30 days after sowing. Variety 'TAG-24' was sown at $30 \mathrm{~cm}$ row spacing. For organic crop protection, seed treated by Tricoderma herzanium @ $8 \mathrm{~g} \mathrm{~kg}^{-1}$ neem seed kernel extract spray $(5 \%)$ at 45 and 60 DAS, fresh neem leaf spray (10\%) along with $0.2 \%$ garlic spray and milk whey $(10 \%)$ spray were done to control insect- pest of crop during cropping season. All the agronomic practices were carried as per recommendation of organic farming. The observations were recorded replication wise in each treatment from randomly selected plants for plant height, pods plant $^{-1}$, kernels weight. Crop productivity was recorded from pod yield of net area converted to hectare and profitability was calculated from net monetary return and soil fertility was calculated through soil sample analysis after completed cropping system.

\section{Results and Discussion}

\section{Growth and yield attributes}

The plant heights, numbers of pods per plant, pod weight, kernels per pod and kernels test weight were significantly influenced by different organic plant resources. Data showed in the table 1 of all the yield attributing characters were found to be higher in the treatments consisting combination of organic manures than individual manure. Organic manures alone meet the lower nutrient demand, but combination of organic manures has become imperative to sustain high nutrient supply for higher productivity. The combined application of FYM@4t ha ${ }^{-1}$ + rock phosphate $@ 260 \mathrm{~kg} \mathrm{ha}^{-1}+$ gypsum@500kg ha ${ }^{1}+$ biofertilizers BD $500 \quad\left(\mathrm{~T}_{11}\right)$ recorded significantly higher plant height $(79.33 \mathrm{~cm})$, pods plant $^{-1}$ (42), kernels pod ${ }^{-1}$ (2.02) and 1000 kernels weight (347g) followed by organic manures combinations of $\mathrm{T}_{6^{-}} \mathrm{T}_{10}$ in the case of plant height, kernels $\operatorname{pod}^{-1}$ and kernels test weight, while, pods plant ${ }^{-1}$ were at par with $\mathrm{T}_{9}-\mathrm{T}_{10}$ and significantly higher over rest treatment, respectively. This might be due to greater conversion of organic sources to available form of plant nutrient to adequate availability of nutrient in root zone to higher uptake by plant for accumulation of biomass in the treatments of combined application of manures. Further, physiological role of nutrients supplied by combination use of organic manures in enhancing growth parameters might have led to increased yield attributes and there by yield of crop. This is attributed to better growth of plants and higher yield by slow release of nutrients for absorption with additional nutrients like gibberellins, cytokinin, and auxins, by the application of organic inputs. These findings are in accordance with Kumawat et al., (2009) and Subrahmaniyan et al., (2000).

\section{Yield}

Data presented in Table 2 revealed that different combination of organic manures had significant effect on the pod, kernel and haulm yield and shelling per cent of groundnut. The maximum pod yield (45.17q ha ${ }^{-1}$ ) was recorded with the combined use of FYM@4t $\mathrm{ha}^{-1}+$ rock phosphate @260kg ha ${ }^{-1}$ +gypsum@500kg ha ${ }^{-1}+$ biofertilizers BD500 $\left(\mathrm{T}_{11}\right)$ followed by organic manures combination of $\mathrm{T}_{8}-\mathrm{T}_{10}$, but it was significantly increased pod yield of groundnut in the tune of 369 per cent over absolute control $\left(9.63 \mathrm{q} \mathrm{ha}^{-1}\right)$ and $11.89,21.85,26.99,35.52,60.35,90.59$ and 93.86 per cent over $T_{7}, T_{6}, T_{1}, T_{3}, T_{4}, T_{5}$ and $\mathrm{T}_{2}$, respectively. These results directly indicated that pod yield was reduced to lower availability of plant nutrient in the soil of treatment of absolute control, bone meal and rock phosphate. Bone meal and rock 
phosphate were recorded very slow nutrient releaser. Similarly, the maximum kernels yield $\left(34.48 \mathrm{q} \mathrm{ha}^{-1}\right)$, haulm yield $\left(76.33 \mathrm{q} \mathrm{ha} \mathrm{h}^{-1}\right)$ and shelling per cent $(73.22 \%)$ were also recorded with combined manures, biofertilizers and BD 500 used in $\mathrm{T}_{11}$. These were recorded same statistically trend as pod yield of groundnut. The positive response to combined application of organic manures might be attributed to the better nutrient availability and its favourable effect on soil physical and biological properties resulting increased yield attributes and finally higher yields. The results are in close agreement with the observation of Kachot et al., (2001), Gunri and Nath (2012) and Ola et al., (2013).

Table.1 Response of organic sources of plant nutrients on growth and yield attributes of groundnut (pooled data 2012-2014)

\begin{tabular}{|c|c|c|c|c|c|}
\hline S.No. & Treatment & $\begin{array}{l}\text { Plant height } \\
\quad(\mathrm{cm})\end{array}$ & Pods plant & $\begin{array}{c}\text { Kernels } \\
\text { pod }^{-1}\end{array}$ & $\begin{array}{c}\text { Test } \\
\text { weight of } \\
\text { kernels }\end{array}$ \\
\hline $\mathbf{T}_{1}$ & $\begin{array}{l}\text { FYM @4t ha- }{ }^{-1}+\text { Rock } \\
\text { Phosphate @260kg ha }\end{array}$ & 73.33 & 30.40 & 1.86 & 333 \\
\hline $\mathbf{T}_{2}$ & $\begin{array}{l}\text { Bone meal @300kg } \mathrm{ha}^{-1} \\
+\mathrm{FYM} @ 2.2 \mathrm{t} \mathrm{ha}^{-1}\end{array}$ & 63.33 & 19.60 & 1.50 & 300 \\
\hline $\mathbf{T}_{3}$ & $\begin{array}{l}\text { Vermicompost@1.5 } \mathrm{ha}^{-1}+ \\
\text { Rock Phosphate @225kg ha }{ }^{-1}\end{array}$ & 68.33 & 28.50 & 1.85 & 320 \\
\hline $\mathbf{T}_{4}$ & $\begin{array}{l}\text { Neem cake @ } 400 \mathrm{~kg} \mathrm{ha}^{-1}+ \\
\text { bone meal @ } 280 \mathrm{~kg} \mathrm{ha}^{-1}\end{array}$ & 65.00 & 24.49 & 1.63 & 300 \\
\hline $\mathbf{T}_{5}$ & $\begin{array}{l}\text { Poultry manure @ } 1.0 \mathrm{t} \mathrm{ha}^{-1}+ \\
\text { Rock phosphate@200 } \mathrm{kg} \mathrm{ha}^{-1}\end{array}$ & 61.33 & 20.62 & 1.51 & 330 \\
\hline$T_{6}$ & $\begin{array}{l}\mathrm{T}_{1}+\text { Seed treatment through } \\
\text { Biofertilizers }\end{array}$ & 70.00 & 32.78 & 1.88 & 337 \\
\hline $\mathbf{T}_{7}$ & $\mathrm{~T}_{6}+$ Gypsum @ 500kg ha ${ }^{-1}$ & 74.00 & 34.52 & 1.89 & 347 \\
\hline $\mathbf{T}_{8}$ & $\begin{array}{l}\mathrm{T}_{6}+\text { gypsum @ } 250 \mathrm{~kg} \mathrm{ha}{ }^{-1} \\
\text { before sowing and } 250 \mathrm{~kg} \mathrm{ha}^{-1} \\
\text { at before flowering }\end{array}$ & 75.00 & 37.33 & 1.91 & 347 \\
\hline $\mathbf{T}_{9}$ & $\begin{array}{l}\mathrm{T}_{8}+\quad \text { green manuring } \\
\text { incorporated at } 20 \mathrm{DAS}\end{array}$ & 76.00 & 40.53 & 1.92 & 347 \\
\hline $\mathbf{T}_{10}$ & $\mathrm{~T}_{8}+$ mulching @ $4 \mathrm{tha}^{-1}$ & 78.00 & 41.78 & 1.95 & 347 \\
\hline $\mathbf{T}_{11}$ & $\mathrm{~T}_{8}+\mathrm{BD} 500$ & 79.33 & 42.00 & 2.02 & 347 \\
\hline \multirow[t]{2}{*}{$\mathbf{T}_{12}$} & Absolute control & 51.67 & 8.67 & 1.23 & 280 \\
\hline & $\mathrm{CD}(\mathrm{P}=0.05)$ & 10.53 & 3.81 & 0.16 & 10.52 \\
\hline
\end{tabular}


Table.2 Response of organic plant nutrient sources on yield and shelling of groundnut (pooled data 2012-2014)

\begin{tabular}{|c|c|c|c|c|c|}
\hline S.No. & Treatment & $\begin{array}{l}\text { Pods yield } \\
\left(\mathbf{q} \mathbf{h a}^{-1}\right)\end{array}$ & $\begin{array}{c}\text { Kernels } \\
\text { yield } \\
\left(\mathbf{q ~ h a} \mathbf{~ h a ~}^{-1}\right)\end{array}$ & $\begin{array}{c}\text { Haulm } \\
\text { yield } \\
\left(\mathbf{q} \text { ha }^{-1}\right)\end{array}$ & $\begin{array}{l}\text { Shelling } \\
(\%)\end{array}$ \\
\hline $\mathbf{T}_{1}$ & $\begin{array}{l}\text { FYM @ } 9 \mathrm{t} \mathrm{ha}^{-1}+\text { Rock } \\
\text { Phosphate @260kg ha }\end{array}$ & 35.57 & 25.36 & 71.33 & 55.00 \\
\hline $\mathbf{T}_{2}$ & $\begin{array}{l}\text { Bone meal @300kg } \mathrm{ha}^{-1} \\
+\mathrm{FYM} @ 2.2 \mathrm{t} \mathrm{ha}^{-1}\end{array}$ & 23.30 & 14.37 & 61.67 & 37.00 \\
\hline $\mathbf{T}_{3}$ & $\begin{array}{l}\text { Vermicompost@ @ 1.5 } \mathrm{th}^{-1}+ \\
\text { Rock Phosphate @225 } \mathrm{kg} \mathrm{ha}^{-1}\end{array}$ & 33.33 & 22.87 & 68.67 & 52.00 \\
\hline $\mathbf{T}_{4}$ & $\begin{array}{l}\text { Neem cake@ @ } 400 \mathrm{~kg} \mathrm{ha}^{-1}+ \\
\text { bone meal @ } 280 \mathrm{~kg} \mathrm{ha}^{-1}\end{array}$ & 28.17 & 17.14 & 61.13 & 47.78 \\
\hline $\mathbf{T}_{5}$ & $\begin{array}{l}\text { Poultry manure @ } 1.0 \mathrm{t} \mathrm{ha}^{-1}+ \\
\text { Rock phosphate@200 } \mathrm{kg} \mathrm{ha}^{-1}\end{array}$ & 23.70 & 14.40 & 60.67 & 45.11 \\
\hline $\mathbf{T}_{6}$ & $\begin{array}{l}\mathrm{T}_{1}+\text { Seed treatment through } \\
\text { Biofertilizers }\end{array}$ & 37.07 & 26.43 & 71.33 & 62.44 \\
\hline $\mathbf{T}_{7}$ & $\mathrm{~T}_{6}+$ Gypsum @500kg ha ${ }^{-1}$ & 40.37 & 29.67 & 73.33 & 63.11 \\
\hline $\mathbf{T}_{8}$ & $\begin{array}{l}\mathrm{T}_{6}+\text { gypsum @ } 250 \mathrm{~kg} \mathrm{ha} \\
\text { before sowing and } 250 \mathrm{~kg} \mathrm{ha}^{-1} \\
\text { at before flowering }\end{array}$ & 41.47 & 31.42 & 75.67 & 65.11 \\
\hline $\mathbf{T}_{9}$ & $\begin{array}{l}\mathrm{T}_{8}+\text { green manuring } \\
\text { incorporated at } 20 \mathrm{DAS}\end{array}$ & 42.56 & 32.21 & 75.67 & 68.11 \\
\hline $\mathbf{T}_{10}$ & $\mathrm{~T}_{8}+$ mulching @ $4 \mathrm{tha}^{-1}$ & 42.97 & 32.54 & 76.00 & 72.22 \\
\hline$T_{11}$ & $\mathrm{~T}_{8}+\mathrm{BD} 500$ & 45.17 & 34.48 & 76.33 & 73.22 \\
\hline \multirow[t]{2}{*}{$\mathbf{T}_{12}$} & Absolute control & 09.63 & 4.79 & 49.33 & 21.33 \\
\hline & $\mathrm{CD}(\mathrm{P}=0.05)$ & 4.14 & 3.29 & 5.62 & 10.23 \\
\hline
\end{tabular}


Table.3 Response of organic plant nutrient sources of economics (pooled data 2012-2014)

\begin{tabular}{|c|c|c|c|c|c|}
\hline S.No. & Treatment & $\begin{array}{c}\text { Cost of } \\
\text { cultivation } \\
\left(\operatorname{Rs~ha}{ }^{-1}\right)\end{array}$ & $\begin{array}{c}\text { Gross } \\
\text { return }(\text { Rs } \\
\left.\text { ha }^{-1}\right)\end{array}$ & $\begin{array}{l}\text { Net return } \\
\left(\mathrm{Rs} \mathrm{ha}^{-1}\right)\end{array}$ & $\mathrm{B}: \mathrm{C}$ ratio \\
\hline $\mathbf{T}_{1}$ & $\begin{array}{l}\text { FYM @ } @ 4 \mathrm{ha}^{-1}+\text { Rock } \\
\text { Phosphate @260kg ha }\end{array}$ & 23520 & 104769 & 81249 & 3.45 \\
\hline $\mathbf{T}_{2}$ & $\begin{array}{l}\text { Bone meal @300kg } \mathrm{ha}^{-1} \\
+ \text { FYM@ } 2.2 \mathrm{t} \mathrm{ha}^{-1}\end{array}$ & 28036 & 81917 & 53880 & 1.92 \\
\hline $\mathbf{T}_{\mathbf{3}}$ & $\begin{array}{l}\text { Vermicompost@1.5t ha }{ }^{-1}+ \\
\text { Rock Phosphate @225kg ha }\end{array}$ & 27550 & 98004 & 70454 & 2.56 \\
\hline $\mathbf{T}_{4}$ & $\begin{array}{l}\text { Neem cake @ } 400 \mathrm{~kg} \mathrm{ha}^{-1}+ \\
\text { bone meal @280kg ha }\end{array}$ & 31600 & 106806 & 75206 & 2.38 \\
\hline $\mathbf{T}_{\mathbf{5}}$ & $\begin{array}{l}\text { Poultry manure @ } 1.0 \mathrm{t} \mathrm{ha}^{-1}+ \\
\text { Rock phosphate@200kg ha }{ }^{-1}\end{array}$ & 22300 & 98902 & 76602 & 3.44 \\
\hline $\mathbf{T}_{6}$ & $\begin{array}{l}\mathrm{T}_{1}+\text { Seed treatment through } \\
\text { Biofertilizers }\end{array}$ & 23770 & 106990 & 83220 & 3.50 \\
\hline $\mathbf{T}_{7}$ & T6+Gypsum @500kg ha ${ }^{-1}$ & 24020 & 118578 & 94558 & 3.94 \\
\hline $\mathbf{T}_{8}$ & $\begin{array}{l}\mathrm{T}_{6}+\text { gypsum @ } 250 \mathrm{~kg} \mathrm{ha}{ }^{-1} \\
\text { before sowing and } 250 \mathrm{~kg} \mathrm{ha}^{-1} \\
\text { at before flowering }\end{array}$ & 24220 & 122016 & 97796 & 4.04 \\
\hline $\mathbf{T}_{9}$ & $\begin{array}{l}\mathrm{T}_{8}+\quad \text { green manuring } \\
\text { incorporated at } 20 \mathrm{DAS}\end{array}$ & 25470 & 118712 & 93242 & 3.66 \\
\hline $\mathbf{T}_{10}$ & $\mathrm{~T}_{8}+$ mulching @ tha ${ }^{-1}$ & 25020 & 126813 & 101793 & 4.07 \\
\hline $\mathbf{T}_{11}$ & $\mathrm{~T}_{8}+\mathrm{BD} 500$ & 24820 & 134388 & 109568 & 4.41 \\
\hline \multirow[t]{2}{*}{$\mathbf{T}_{12}$} & Absolute control & 20700 & 49367 & 28667 & 1.38 \\
\hline & $\mathrm{CD}(\mathrm{P}=0.05)$ & & 3566 & 3566 & 0.15 \\
\hline
\end{tabular}


Table.4 Response of organic plant nutrient sources on soil fertility status after groundnut harvest

\begin{tabular}{|c|c|c|c|c|c|}
\hline S.No. & Treatment & $\begin{array}{l}\text { Organic } \\
\text { carbon } \\
(\%)\end{array}$ & $\begin{array}{c}\text { Available } \\
\text { nitrogen } \\
\left(\mathrm{kg} \mathrm{ha}^{-1}\right)\end{array}$ & $\begin{array}{l}\text { Available } \\
\text { phosphorus } \\
\left.\text { (kg ha }^{-1}\right)\end{array}$ & $\begin{array}{c}\text { Availability } \\
\text { Potassium } \\
\left(\mathrm{kg} \mathrm{ha}^{-1}\right)\end{array}$ \\
\hline $\mathbf{T}_{1}$ & $\begin{array}{l}\text { FYM @ } 4 \mathrm{t} \mathrm{ha}{ }^{-1}+\text { Rock } \\
\text { Phosphate @260kg ha }\end{array}$ & 0.77 & 221.64 & 29.12 & 284.60 \\
\hline $\mathbf{T}_{2}$ & $\begin{array}{l}\text { Bone meal @ } 300 \mathrm{~kg} \mathrm{ha}^{-1} \\
+\mathrm{FYM} @ 2.2 \mathrm{t} \mathrm{ha}^{-1}\end{array}$ & 0.69 & 173.56 & 31.10 & 267.33 \\
\hline $\mathbf{T}_{3}$ & $\begin{array}{ll}\text { Vermicompost } @ 1.5 \mathrm{tha}^{-1} \\
+\quad \mathrm{Rock}^{-} \text {Phosphate } \\
@ 225 \mathrm{~kg} \mathrm{ha}^{-1}\end{array}$ & 0.72 & 206.48 & 32.94 & 285.67 \\
\hline $\mathbf{T}_{4}$ & $\begin{array}{l}\text { Neem cake @ } 400 \mathrm{~kg} \mathrm{ha}^{-1}+ \\
\text { bone meal @ } 280 \mathrm{~kg} \mathrm{ha}^{-1}\end{array}$ & 0.64 & 218.00 & 34.87 & 282.67 \\
\hline $\mathbf{T}_{5}$ & $\begin{array}{l}\text { Poultry manure @ } 1.0 \mathrm{t} \mathrm{ha}^{-1} \\
\text { + Rock phosphate@200kg } \\
\text { ha }^{-1}\end{array}$ & 0.69 & 204.68 & 36.48 & 287.00 \\
\hline $\mathbf{T}_{6}$ & $\begin{array}{l}\mathrm{T}_{1}+\text { Seed treatment } \\
\text { through Biofertilizers }\end{array}$ & 0.80 & 226.92 & 32.47 & 295.00 \\
\hline $\mathbf{T}_{7}$ & $\mathrm{~T}_{6}+$ Gypsum @ 500kg ha ${ }^{-1}$ & 0.83 & 270.60 & 36.92 & 300.67 \\
\hline $\mathbf{T}_{8}$ & $\begin{array}{l}\mathrm{T}_{6}+\text { gypsum @ } 250 \mathrm{~kg} \mathrm{ha}^{-1} \\
\text { before sowing and } 250 \mathrm{~kg} \\
\mathrm{ha}^{-1} \text { at before flowering }\end{array}$ & 0.84 & 274.66 & 37.00 & 302.60 \\
\hline $\mathbf{T}_{9}$ & $\begin{array}{l}\mathrm{T}_{8}+\text { green manuring } \\
\text { incorporated at } 20 \mathrm{DAS}\end{array}$ & 0.88 & 292.40 & 38.94 & 311.33 \\
\hline $\mathbf{T}_{10}$ & $\mathrm{~T}_{8}+$ mulching@4 tha ${ }^{-1}$ & 0.89 & 286.48 & 37.33 & 319.53 \\
\hline $\mathbf{T}_{11}$ & $\mathrm{~T}_{8}+\mathrm{BD} 500$ & 0.86 & 280.83 & 39.20 & 311.22 \\
\hline \multirow[t]{2}{*}{$\mathbf{T}_{12}$} & Absolute control & 0.41 & 118.56 & 16.76 & 181.67 \\
\hline & $\mathrm{CD}(\mathrm{P}=0.05)$ & 0.06 & 19.96 & 3.6 & 22.23 \\
\hline
\end{tabular}

\section{Economics}

The data on cost of cultivation, gross return, net return and benefit cost ratio of groundnut as influenced by organic sources of plant nutrient are presented in table 3. Among the different organic treatments, the cost of cultivation varied from Rs. 20700 to Rs.31600 $\mathrm{ha}^{-1}$. The maximum cost of cultivation (Rs. $31600 \mathrm{ha}^{-1}$ ) was calculated of 
the combined used of neem cake $\left(400 \mathrm{~kg} \mathrm{ha}^{-1}\right)$ + bone meal $\left(280 \mathrm{~kg} \mathrm{ha}^{-1}\right)$ and minimum cost of cultivation (Rs $20700 \mathrm{ha}^{-1}$ ) was recorded in absolute control due to without use of organic plant nutrient sources. The maximum gross return of Rs. 1,34,388 $\mathrm{ha}^{-1}$ and net return of Rs.1,09,568 ha ${ }^{-1}$ and $\mathrm{B}: \mathrm{C}$ ratio of 4.41 were calculated in a treatment having combined application of FYM@ $4 \mathrm{t} \mathrm{ha}^{-1}+$ rock phosphate @260kg ha $\mathrm{ha}^{-1}+$ gypsum@500kg ha $\mathrm{ha}^{-1}+$ biofertilizers + BD $500\left(\mathrm{~T}_{11}\right)$. The gross return, net return and $\mathrm{B}: \mathrm{C}$ ratio under $\mathrm{T}_{11}$ were recorded significantly higher over rest treatment. These values might be higher due higher pod yield with low input purchasing cost compared to other treatment. These results are conformity with findings of Ram et al., (2013), Sharma et al., (2013) and Hargilas and Sharma (2015).

\section{Soil fertility status}

The nutrient availability in the soil revealed that application of different sources of plant nutrient influenced the per cent organic carbon, available nitrogen, phaphorus and potassium in the soil after harvesting of groundnut (Table 4). The combined application of FYM@ 4t $\mathrm{ha}^{-1}+$ rock phosphate@260kg ha ${ }^{-1}+$ gypsum@500kg $\mathrm{ha}^{-1}+$ biofertilizers + crop residual mulching $@ 4 \mathrm{tha}^{-1}\left(\mathrm{~T}_{10}\right)$ recorded significantly higher soil organic carbon $(0.89 \%)$ over $\mathrm{T}_{1}-\mathrm{T}_{6}$ and $\mathrm{T}_{10}$, respectively. Whereas, this treatment combination statistically at par with $\mathrm{T}_{7}-\mathrm{T}_{9}$. The lesser organic carbon increased in treatment of neem cake +bone meal and organic carbon in the soil decreased continuously in absolute control after harvesting of groundnut. The organic carbon per cent in the soil might be affected to addition of quantity of low concentrated organic manures. Compared to initial nitrogen availability in the soil, there was improvement in actual $\mathrm{N}$ status under combined use of all organic nutrient sources. While, nitrogen availability was reduce in individual $\mathrm{N}$ resources used. The maximum available $\mathrm{N}\left(292.40 \mathrm{~kg} \mathrm{ha}^{-1}\right)$ recorded in combined application of FYM+rock phosphate+biofertilizers+gypsum+ green manuring $\left(\mathrm{T}_{9}\right)$ followed by $\mathrm{T}_{8}, \mathrm{~T}_{10}$ and $\mathrm{T}_{11}$ and it significantly higher over rest treatments. The maximum available phosphorus $(39.20 \mathrm{~kg}$ $\mathrm{ha}^{-1}$ ) was recorded under FYM@ $4 \mathrm{t} \mathrm{ha}^{-1}+$ rock phosphate @ 260kg ha ${ }^{-1}+$ gypsum@500kg ha ${ }^{-1}+$ biofertilizers+ BD500 $\left(\mathrm{T}_{11}\right)$ followed by $\mathrm{T}_{7}-\mathrm{T}_{10}$ and $\mathrm{T}_{5}$ and significantly higher over rest treatments. The higher available potassium was recorded in combined use of FYM@ 4t ha ${ }^{-1}+$ rock phosphate@260kg ha-1 + gypsum@500kg $\mathrm{ha}^{-1}+$ residual mulching $\left(\mathrm{T}_{10}\right)$ followed by $\mathrm{T}_{7-}$ $\mathrm{T}_{9}$ and $\mathrm{T}_{11}$ and significantly higher over rest treatments. The availability of nutrient in soil after harvesting of crop might be depending on addition of organic resources in the soil. The results of experiment are strongly support the finding of Deshmukh et al., (2005) and Hargilas and Sharma (2015).

On the basis of field experimentation, it can be concluded that combined application of FYM, rock phosphate, gypsum with biofertilizer and mulching in the groundnut cultivation favoured for better nutrition to higher productivity and profitability with enrichment of soil fertility status under humid zone of Southern Rajasthan

\section{References}

DAC\&FW,2016.Agricultural at a glance, 2016. DAC \& FW, Ministry of Agriculture \& Farmers Welfare, Government of India, New Delhi.

Deshmukh, K.K, Khatik, S.K. and Dubey, D.P. 2005. Effect of Integrated use of inorganic, organic and bio fertilizers on production, Nutrient availability of plateau and Satpura hills. Journal of Soils and Crops, 15: 21-25.

Ghosh PK, KG Mandal, KK Bandyopadhyay, 
KM Hati, A Subba Rao, AK Tripathi (2002). Role of plant nutrient management on oilseed production. Fertiliser News, 47(11): 67-77.

Gunri, S.K. and Nath, R. 2012.Effect of organic manures, bio-fertilizers and biopesticides on productivity of summer groundnut (Arachis hypogaea L.) in red and laterite zone of West Bengal. Legume Research, 35(2): 144-148.

Hargilas and Sharma, S.N. 2015. Effect of different combinations of organic manures and biofertilizers on growth, yield, grain quality and economics in organic farming of scented rice. Journal of Plant Development Sciences, 7(5): 381-388

Kachot, N.A., Malavia, D.D., Solanki, R.M. and Sagarka, B.K. 2001.Integrated nutrient management in rainy season groundnut (Arachis hypogea L). Indian Journal of Agronomy, 46 (3): 516-522.

Kumawat, R.N., Mahajan, S.S., Mertia, R.S.2009. Growth and development of groundnut (Arachis hypogaea) under foliar application of panchgavya and leaf extracts of endemic plants. Indian Journal of Agronomy, 54(3): 324-331.

Laxminarayana, K. and Patsram, 2005. Influence of inorganic, biological and organic manures on yield and nutrient uptake sf groundnut (Arachis hypogaea L.) and soil properties. Indian journal of Agricultural sciences.75 (4):218-21.

Nziguheba G, Palm, C.A., Buresh, R.J, Smithson, P.C. 1998.Soil phosphorus fractions and adsorption as affected by organic and inorganic sources. Plant and
Soil 198: 159-168.

Ola, B. L., Pareek, B. L., Yadav, R. S., Shivran, A. C. and Sharma, O. P. (2013). Influence of integrated nutrient management on productivity and quality of groundnut in western Rajasthan. Annals of Agricultural Research New Series 34: 156-159.

Ram Chatra, Singh, H. B., Patel, R. B., Singh, Hanuman and Kumar, Gopal. 2013. Effect of various nutrient sources on productivity and economics of groundnut. Annals of Agricultural Research New Series 34: 176-178.

Sharma, Sheela, Jat, N. L., Shivran, A. C., Choudhary, Shripal, Puniya, M. M. and Jeetarwal, R. L. (2013).Effect of fertility levels and bio- fertilizers on yield and economics of groundnut. Annals of Agricultural Research New Series 34: 353-356.

Sriramachandrasekaran, M.V. 2001.Effect of industrial and organic wastes on groundnut in typic ustifluvent soil. American Agriculture. Research, New series, 22(3): 436-438

Stevenson FJ (1994). Humus Chemistry: Genesis, Composition, Reactions, Second edition John Wiley \& Sons Inc. New York.

Subrahmaniyan K, P Kalaiselvan, N Arulmozhi (2000). Studies on the effect of nutrient spray and graded level of NPK fertilizers on the growth and yield of groundnut. International Journal of Tropical Agriculture, 18(3): 287-290.

\section{How to cite this article:}

Hargilas. 2018. Response of Organic Plant Nutrient Sources on Productivity and Profitability of Groundnut (Arachis hypogaea L.) and Soil Fertility under Humid Zone of Southern Rajasthan. Int.J.Curr.Microbiol.App.Sci. 7(12): 2044-2052.

doi: https://doi.org/10.20546/ijcmas.2018.712.235 